Original Research Paper

\title{
The Effect of Young Leaves Extract of Arumanis Mango as an Antidepressant in Zebrafish (Danio rerio)
}

\author{
Risda Arba Ulfa ${ }^{{ }^{*}}$, Tri Cahyanto ${ }^{1}$, Ikeu Winda Larasati $^{1}$, Adisty Virakawugi Darniwa ${ }^{1}$, \\ Ayuni Adawiyah $^{1}$, Afriansyah Fadillah ${ }^{1}$ \\ ${ }^{1}$ Department of Biology, UIN Sunan Gunung Djati, Bandung, West Java, Indonesia
}

\author{
Article History \\ Received : December $05^{\text {th }}, 2021$ \\ Revised : December $22^{\text {th }}, 2021$ \\ Accepted : December $30^{\text {th }}, 2021$ \\ Published : January $05^{\text {th }}, 2022$ \\ *Corresponding Author: \\ Risda Arba Ulfa, \\ Department of Biology, UIN \\ Sunan Gunung Djati, Bandung, \\ West Java, Indonesia \\ Email: \\ risdaarbaulfa@uinsgd.ac.id
}

\begin{abstract}
Sustained stress is risked for the emergence of various diseases including disability to depression. Clinically, antidepressant drugs are still the main option even though they are known have side effects for users. Therefore, various types of drug plants that have the potential as natural antidepressants have begun to be used, one of them is the young leaf of mango (Mangifera indica). It is known contains various bioactive compounds, including mangiferin which is useful as an antioxidant, antiinflammatory, and plays a role in protecting nervous tissue. This study aimed to determine the effect of Mango's young leaves extract of Arumanis cultivar as an antidepressant in zebrafish (Danio rerio) exposed to Unpredictable Chronic Stress (UCS). The method used is Completely Randomized Design (CRD) which consists of 3 treatments, namely K (Aquadest); P1 (extract concentration $10 \mu \mathrm{g} / \mathrm{mL}$ ); and P2 (extract concentration $20 \mu \mathrm{g} / \mathrm{mL}$ ). The parameters include the antioxidant activity and behavioral tests, namely new tank diving and light/dark preferences. The results showed that exposure to UCS tends to increased anxiety as indicated by a decrease in exploration on behavioral test. The data showed that the Mango's young leaves extract induction with a concentration of $20 \mu \mathrm{g} / \mathrm{mL}$ obtained the highest value percentage in the exploration of the upper area $(36.8 \mathrm{~s})$ and the preference of the bright area $(90.8 \mathrm{~s})$ significantly. The induction of mango's young leaves extract has the potential as an antidepressant in zebrafish exposed to UCS with an optimal concentration of $20 \mu \mathrm{g} / \mathrm{ml}$.
\end{abstract}

Keywords: Antioxidant activity, Antidepressant, Behavioral test, Mango's young leaves extract

\section{Pendahuluan}

Stres didefinisikan sebagai pola reaksi dan adaptasi dari suatu organisme terhadap adanya ancaman yang disebut sebagai stressor (Aponte \& Petrunich, 2019). Stres kronis merupakan salah satu kasus yang banyak terjadi akibat pendedahan lebih dari satu jenis stressor dan berlangsung pada periode waktu lama sehingga berpotensi pada tingkatan stres yang komplek seperti depresi (Collier et al., 2017). Sejauh ini, stres maupun depresi ditangani melalui pemberian berbagai jenis obat antidepresan sintetik. Umumnya cara kerja obat antidepresan sintetik ialah menghambat sistem endokrin maupun monoaminergik (Adelina, 2013).
Namun, dalam perkembangannya berbagai hasil penelitian menunjukan adanya efek samping dari penggunaan obat sintetik ini seperti mual, muntah, sakit kepala, mulut kering, otot kaku, hingga mengganggu sistem pernafasan dan pencernaan (Kurama et al., 2013). Oleh karena itu, saat ini mulai banyak dilakukan penelitian terkait dengan berbagai jenis tanaman herbal yang berpotensi sebagai antidepresan alami, termasuk pucuk mangga.

Pemanfaatan tanaman mangga dalam dunia medis selalu identik dengan keberadaan senyawa golongan flavonoid yaitu mangiferin. Senyawa ini dapat ditemui pada seluruh bagian tanaman mangga mulai dari akar hingga buah bahkan bijinya (Pokorski, 2013). Senyawa 
mangiferin diketahui memiliki potensi farmakologis sebagai antinyeri, antioksidan, antiimflamasi, antihipertensi, antivirus, antialergi, hipolipidomia, antikanker, antinyeri hingga antidepresi (Prommajak et al., 2014). Berdasarkan hasil penelitian terdahulu, kandungan mangiferin pada pucuk mangga dapat dipengaruhi oleh jenis kultivarnya. Dengan membandingkan lima jenis kultivar dari tanaman mangga yang meliputi Manalagi, Arumanis, Cengkir, Gedong apel dan Golek dilaporkan bahwa kadar mangiferin tertinggi diperoleh pucuk dari tanaman mangga Arumanis yang mencapai 20,83\% (Cahyanto et al., 2020).

Banyak penelitian telah dilakukan untuk mengetahui potensi dari pucuk mangga Arumanis sebagai tanaman herbal yang berperan dalam mencegah maupun mengobati berbagai jenis penyakit. Seperti penelitian yang dilakukan oleh Zulfiqar (2018), menyimpulkan bahwa ekstrak etanol daun mangga Arumanis dapat menurunkan kadar glukosa darah mencit pada konsentrasi maksimal sebesar $500 \mathrm{mg} / \mathrm{kgBB}$. Penelitian lain dilakukan Rahmawati (2020), melaporkan bahwa penggunaan ekstrak daun mangga arumanis pada konsentrasi $1600 \mathrm{mg} / \mathrm{mL}$ mampu membentuk zona inhbisi Propionibacterium acne hingga $21,5 \mathrm{~mm}$.

Sebagai bentuk pengembangan, penelitian ini kemudian dirancang dengan tujuan mengetahui pengaruh ekstrak pucuk mangga Arumanis sebagai antidepresan mengingat tingginya kandungan mangiferin pada kultivar ini. Penelitian tentang potensi pucuk mangga dari kultivar Arumanis sebagai antidepresan masih sangat jarang dilakukan. Selain itu, penggunaan ikan zebra (Danio rerio) yang diketahui memiliki hampir $70 \%$ gen-gen penyakit yang homolog secara fungsional dengan manusia (Khan\& Alhewairini, 2019), diharapakan mampu menunjang validitas dari hasil penelitian. Selanjutnya, induksi stres kronis melalui pendedahan UCS yang secara umum biasa digunakan sebagai metode pencarian obat antidepresan dilakukan dengan cara pemberian stressor lebih dari satu terhadap hewan model secara terus-menerus dan berlangsung dalam rentang waktu minimal tujuh hari. Menurut Song et al., (2018), paparan UCS dapat meningkatkan kadar hormon yang berkorelasi dengan perilaku hewan uji seperti kecemasan hingga depresi. Hasil dari penelitian ini diharapkan dapat menjadi sumber referensi terkait dengan fungsi farmakologis pucuk mangga Arumanis sebagai antidepresan alami.

\section{Bahan dan Metode}

\section{Lokasi dan Waktu}

Penelitian ini dilaksanakan di Laboratorium Terpadu UIN Sunan Gunung Djati Bandung. Pelaksanaan penelitian dilakukan mulai dari bulan Januari - Juni 2021.

\section{Alat dan Bahan}

Alat-alat yang digunakan terdiri dari akuarium pemeliharaan PxLxT $(35 \times 25 \times 27)$, akuarium berbentuk trapezium (bawah $22,5 \mathrm{x}$ atas 27,9 x lebar 7,1 x tinggi $15,2 \mathrm{~cm}$ ), akuarium berukuran $(40 \times 25 \times 25)$, blender, aerator, erlenmeyer, gelas ukur, gelas kimia, labu evaporator, ice maker, termometer, neraca analitik digital, rotary evaporator (Buchi R-215), kamera DSLR Nikon P520, dan Spektrofotometri Uv-Vis (Agilent Technologies Cary 60).

Bahan yang digunakan pada penelitian ini meliputi hewan uji yaitu ikan zebra yang diperoleh dari toko Legend Aquarium (Jl. Soekarno Hatta Bandung) dengan ukuran berkisar 2,5-3 cm dan rerata usia 7 bulan. Selanjutnya, pucuk mangga Arumanis yang berasal dari perkebunan mangga di Desa Suganangan Kecamatan Cipicung Kabupaten Kuningan. Bahan lain yang digunakan yaitu Metanol (pro analys), Pereaksi DPPH (Sigma aldrick, Jerman), Asam Ascorbat (Pro Analys) aquades, alumunium foil, pakan ikan (Tetra Bits Complex), sarungan tangan, pereaksi mayer, pereaksi wagner, pereaksi dragendoff, $\mathrm{HCl}$ pekat, $\mathrm{FeCl} 31 \%$ serta serbuk $\mathrm{Mg}$.

\section{Pembuatan Ekstrak Pucuk Mangga}

Tahap awal pembuatan ekstrak dimulai dengan sampel pucuk mangga disortasi basah, lalu ditimbang dan dicuci bersih dengan air mengalir. Setelah didiamkan selama 24 jam, pucuk kemudian dikeringkan tanpa terpapar sinar matahari langsung selama sekitar 7 hari. Sampel yang sudah mengering selanjutnya dirajang dan dihaluskan dengan blander dan disaring hingga mendapatkan sampel lebih halus (Permatasari et al., 2018). 
Setiap 150gr sampel kering yang telah dihaluskan, kemudian dimaserasi bertingkat menggunakan methanol absolute sebanyak 450ml selama 3 hari. Penyaringan residu dari hasil maserasi dilakukan dengan menggunakan kertas saring. Selanjutnya proses ekstraksi dilanjutkan menguapkan pelarut pada suhu $50^{\circ} \mathrm{C}$ menggunakan alat rotary evaporator sehingga diperoleh ekstrak dengan tekstur yang kental (Ningsih et al., 2017).

\section{Prosedur Penelitian}

Ikan zebra dipelihara di dalam akuarium pemeliharaan berukuran $35 \times 25 \times 27 \mathrm{~cm}$ dan ditempatkan pada ruangan dengan suhu $25 \pm 1{ }^{\circ} \mathrm{C}$, $\mathrm{pH}$ 6,5-7, dan pencahayaan terang dan gelap yaitu 14:10. Air dalam akuarium pemeliharaan diganti setiap 2 hari sekali untuk memastikan kebersihannya tetap terjaga. Pakan ikan diberikan sebanyak 2 kali dalam sehari (Aponte $\&$ Petrunich, 2019). Sebelum pemberian perlakuan, hewan uji terlebih dahulu diaklimatisasi pada kondisi lingkungan yang homogen selama 7 hari. Penelitian ini merupakan penelitian eksperimental menggunakan metode Rancangan Acak Lengkap (RAL) yang terdiri dari 3 kelompok perlakuan yaitu K (kontrol/ aquades), P1 (ekstrak pucuk mangga $10 \mu \mathrm{g} / \mathrm{mL}$ ), dan P2 (ekstrak pucuk mangga $10 \mu \mathrm{g} / \mathrm{mL}$ ). Sebanyak 90 ekor ikan dibagi ke dalam tiga akuarium sesuai dengan kelompok perlakuan yang telah ditentukam. Masingmasing kelompok perlakuan kemudian didedahkan Unpredictable Chronic Stress (UCS) selama tujuh hari. Berikut merupakan hasil modifikasi jadwal pemberian stres selama periode penelitian (Tabel 1) (Rambo et al., 2017).

Tabel 1. Prosedur pelaksanaan pendedahan Unpredictable Chronic Stress (UCS)

\begin{tabular}{ccccccc} 
Senin & Selasa & Rabu & Kamis & Jum'at & Sabtu & Minggu \\
\hline 09.50 & 08.00 & 09.00 & 08.00 & 08.45 & 07.30 & 08.30 \\
$(\mathrm{CR})$ & $(\mathrm{TC})$ & $(\mathrm{LW})$ & $(\mathrm{H})$ & $(\mathrm{I})$ & $(\mathrm{C})$ & $(\mathrm{CS})$ \\
\hline 14.00 & 15.30 & 12.00 & 16.15 & 14.30 & 13.00 & 13.30 \\
$(\mathrm{I})$ & $(\mathrm{C})$ & $(\mathrm{CR})$ & $(\mathrm{CS})$ & $(\mathrm{TC})$ & $(\mathrm{LW})$ & $(\mathrm{H})$
\end{tabular}

Keterangan:

a. Crowding (CR):10 ekor ikan diletakkan di dalam gelas kimia $250 \mathrm{ml}$ berisi ais selama 50 menit;

b. Social isolation (I): setiap individu ikan dipisahkan dari koloninya dalam gelas kimia $250 \mathrm{ml}$ berisi air selama 45 menit;

c. Tank change (TC): ikan dipindah kan dan diganti tangki penampungan sebanyak 3x secara berturut-turut;

d. Low water level (LW): ikan dipindahkan pada tangki penampungan yang diisi air hanya sampai permukaan punggung ikan terbuka selama 2 menit;

e. Cooling (C): ikan disimpan pada tangki air dengan suhu $23^{\circ} \mathrm{C}$ selama 30 menit;

f. Heating $(\mathrm{H})$ : ikan disimpan pada tangki air dengan suhu $33^{\circ} \mathrm{C}$ selama 30 menit;

g. Chasing (CS): ikan dikejar dengan jaring ikan dalam penampungan selama 8 menit.

Setelah pendedahan UCS, selanjutnya hewan uji akan diberi perlakuan perendaman ekstrak pucuk mangga berdasarkan konsentrasi yang telah ditentukan (hasil uji toksisitas) selama 7 hari. Perendaman ekstrak dilakukan setiap hari selama penelitian pada pukul 09.00 WIB dengan lama perendaman yaitu 20 menit (Stewart et al., 2010).

\section{Skrining Fitokimia}

Pengujian skrining fitokimia dilakukan secara kualitatif untuk mengetahui kandungan senyawa alkaloid (Muthmainnah, 2017), flavonoid (Ikalinus et al., 2015), saponin (Rinaldi et al., 2016), dan tanin (Muthmainnah, 2017).

\section{Uji Aktivitas Antioksidan}

Prosedur penelitian dilakukan dengan cara membuat larutan DPPH pada konsentrasi $50 \mathrm{ppm}$ dengan melarutkan $5 \mathrm{mg}$ DPPH dalam methanol dan dihomogenkan pada labu ukur gelap lalu dicukupkan hingga volume akhir $100 \mathrm{~mL}$. Selanjutnya, dibuat larutan sampel dari ekstrak pucuk mangga pada 5 seri konsentrasi mulai dari 10, 20, 30, 40, dan 50 ppm. Masing-masing $1 \mathrm{~mL}$ larutan ekstrak dicampurkan dengan $3 \mathrm{~mL}$ 
larutan DPPH 50 ppm, dihomogenkan dan dibiarkan selama 30 menit pada tempat gelap. Pengukuran nilai absorbansi dilakukan menggunakan spektrofotometer UV-Vis pada panjang gelombang maksimal $(516 \mathrm{~nm})$ dengan pengulangan sebnyak tiga kali dengan vitamin $\mathrm{C}$ sebagai pembanding. Perhitungan aktivitas antioksidan dilakukan berdasarkan persentase inhibisi menggunakan rumus:

$$
\% \text { Inhibisi }=\frac{(\text { Abs blanko }- \text { Abs sampel })}{\text { Abs blanko }} \times 100 \%
$$

Nilai $\mathrm{IC}_{50}$ diperoleh melalui persamaan regresi linier $(y=a x+b)$ dengan nilai y yaitu 50 , dan $\mathrm{x}$ sebagai $\mathrm{IC}_{50}$. Nilai $\mathrm{IC}_{50}$ ini menunjukkan kemampuan suatu senyawa dalam menghambat radikal bebas sebesar $50 \%$ (Hartanti et al., 2021).

\section{Uji Perilaku}

\section{Uji Novel Tank}

Akuarium berbentuk trapesium diisi dengan air hingga ketinggian mencapai $11,5 \mathrm{~cm}$. Pada bagian terluar akuarium, terdapat garis pemisah antara bagian atas dan bawah masingmasing berkisar $5,75 \mathrm{~cm}$. Uji ini dilakukan untuk mengamati perilaku ikan pada setiap bagain sisi atas dan bawah dengan memasukkan setiap individu ikan zebra ke dalam akuarium selama 6 menit. (Cachat et al., 2014).

\section{Uji Prefensi Terang/ Gelap}

Uji ini menggunakan aquarium berukuran $40 \times 25 \times 25 \mathrm{~cm}$ yang memiliki dua sisi yaitu gelap dan terang. Akuarium tersebut kemudian diisi air sebanyak 5L. Selanjutnya, setiap individu ikan dimasukkan pada akuarium selama 5 menit untuk diamati perilaku preferensi ikan pada sisi gelap maupun terang (Gebauer et al., 2011).

\section{Hasil dan Pembahasan}

\section{Skrining Fitokimia dan Aktivitas Antioksidan Ekstrak Pucuk Mangga}

Skrining fitokimia merupakan salah satu cara untuk mengetahui kandungan senyawa aktif dari suatu bahan tanaman. Berikut adalah hasil uji metabolit sekunder dari ekstrak pucuk mangga Arumanis yang disajikan pada Tabel 2.

Tabel 2. Hasil skrining fitokimia ekstrak pucuk daun mangga Arumanis

\begin{tabular}{llc}
\hline \multicolumn{1}{c}{ Uji Fitokimia } & \multicolumn{1}{c}{ Pengamatan } & Hasil \\
\hline Alkaloid & & \\
Wagner & Terbentuk endapan merah/ merah pekat & + \\
Mayer & Terbentuk endapan putih/ kekuningan & + \\
Dragendroff & Terbentuk endapan warna jingga & + \\
\hline Flavonoid & Terbentuknya warna oranye /merah & + \\
\hline Saponin & Terbentuknya busa stabil selama 5 menit & + \\
\hline Tanin & Terbentuknya biru tua / kehitaman & \\
\hline
\end{tabular}

Berdasarkan uji kuantatif metabolit sekunder dari ekstrak pucuk mangga diketahui positif mengandung senyawa flavonoid, alkaloid, tanin dan saponin. Hal ini sesuai dengan hasil penelitian Cahyanto et al., (2020), yang menyatakan bahwa pucuk mangga kultivar Arumanis diketahui positif mengandung senyawa aktif alkaloid, flavonoid, safonin dan juga tanin. Mangiferin merupakan salah satu senyawa kelompok flavonoid yang diketahui banyak terkandung pada tanaman mangga dan memiliki aktivitas antioksidan yang sangat kuat. Senyawa mangiferin juga berperan sebagai antioksidan yang mampu meregenerasi sel-sel yang telah rusak (Lailly et al., 2016).
Hasil skrining fitokimia yang positif menunjukkan adanya kandungan senyawa aktif dalam ekstrak pucuk mangga, ditindak lanjuti dengan tahap pengujian selanjutnya yaitu uji aktivitas antioksidan. Aktivitas antioksidan dalam suatu senyawa atau sampel tanaman diukur berdasarkan kemampuannya untuk mengambil satu elektron dan metode yang umum digunakan adalah uji DPPH (2,2-difenil-1-pikrihidrazil). Mekanisme kerja antioksidan dalam menstabilkan radikal bebas dilakukan dengan cara mendonorkan atom hidrogen miliknya untuk dapat berikatan dengan atom hidrogen dari radikal bebas sehingga berubah menjadi non radikal (Albaar, 2015). Besarnya aktivitas 
antioksidan dilihat berdasarkan nilai $\mathrm{IC}_{50}$, yaitu konsentrasi larutan sampel yang mampu menghambat $50 \%$ radikal bebas DPPH (Purwanto et al., 2017).
Pada Gambar 1, terlihat grafik hasil perbandingan persentase inhibisi dengan konsentrasi sampel yang diperoleh dari ekstrak metanol pucuk mangga dan vitamin $\mathrm{C}$ sebagai pembanding.

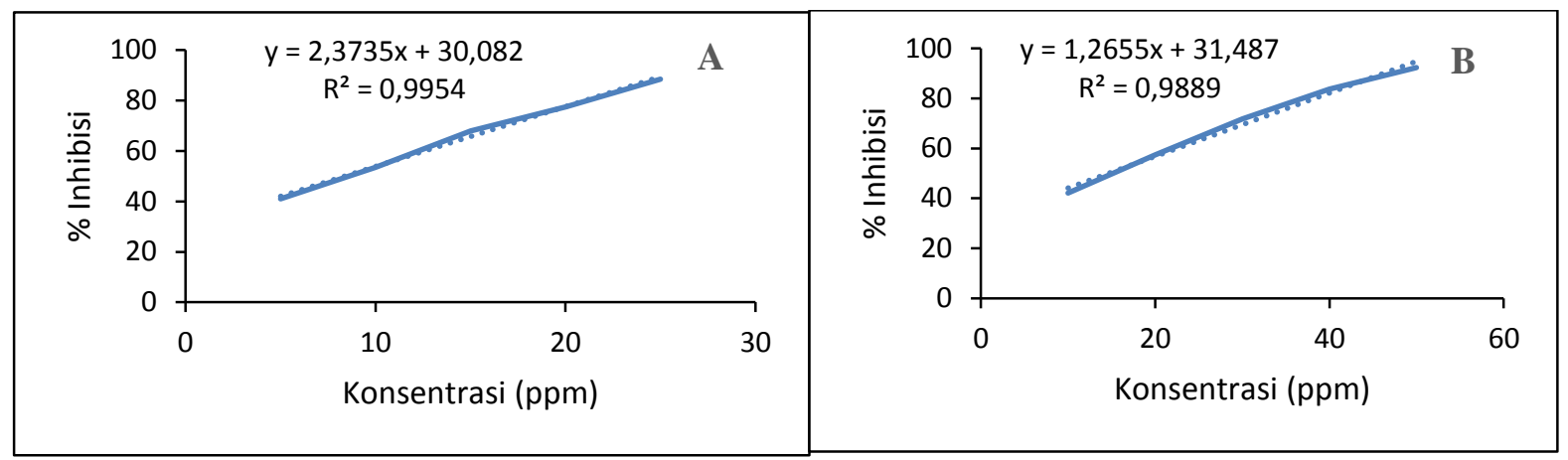

Gambar 1. Grafik hasil pengukuran absorbansi dan nilai \% inhibisi (A) Vitamin C; dan (B) Ekstrak Pucuk Mangga.

Dari grafik tersebut, selanjutnya dapat dihitung nilai $\mathrm{IC}_{50}$ melalui persamaan regresi linier dengan rumus $\mathrm{y}-\mathrm{ax}+\mathrm{b}\left(\mathrm{x}=\mathrm{IC}_{50} ; \mathrm{y}=50\right)$. Nilai regresi linier semakin valid jika $\mathrm{R} 2$ semakin mendekati nilai 1 (satu). Nilai IC $_{50}$ dari ekstrak pucuk mangga dan vitamin $\mathrm{C}$ dapat dilihat pada Tabel 3.

Tabel 3. Nilai $\mathrm{IC}_{50}$ dari Vitamin $\mathrm{C}$ dan Ekstrak Pucuk Mangga

\begin{tabular}{lcc}
\hline \multicolumn{1}{c}{ Sampel } & IC $_{\mathbf{5 0}}$ & Kategori Antioksidan \\
\hline Vit C & 8.39 & Sangat Kuat \\
\hline $\begin{array}{l}\text { Ekstrak Pucuk } \\
\text { Mangga }\end{array}$ & 14.63 & Sangat Kuat \\
\hline
\end{tabular}

Berdasarkan tabel di atas, nilai $\mathrm{IC}_{50}$ yang diperoleh ekstrak pucuk mangga yaitu 14.63 ppm dan masuk dalam ketegori aktivitas antioksidan sangat kuat. Penentuan klasifikasi aktivitas antioksidan didasarkan pada 5 kategori yaitu sangat kuat $\left(\mathrm{IC}_{50}<50\right)$, kuat (50-100), sedang (100-150), lemah (150-200), dan sangat lemah $\left(\mathrm{IC}_{50}>200\right)$ (Rahmayani et al. 2013). Semakin kecil nilai $\mathrm{IC}_{50}$ suatu sampel, maka aktivitas antioksidannya semakin tinggi (Tristantini et al., 2016).

Peran antioksidan sebagai antidepresan mengacu pada salah satu fungsinya dalam mencegah reaksi oksidasi, termasuk stres oksidatif (Es-safi et al., 2021). Aktivitas antioksidan pada ekstrak pucuk mangga yang sangat kuat, menjadikan ektrak ini berpotensi dangat baik dalam mekanisme pemulihan tubuh dari stres sebagai produk antidepresan alternatif.

\section{Pengaruh Ekstrak Pucuk Mangga terhadap Perilaku Ikan Zebra dengan Pendedahan UCS}

Secara fisiologi, ikan zebra sangat sensitif terhadap ancaman yang berasal dari berbagai stessor mulai dari perubahan lingkungan yang tiba-tiba, paparan senyawa kimia, tekanan mekanik ataupun sosial baik secara akut maupun kronis (Collier et al., 2017). Stres kronis yang menyerang ikan dewasa menyebabkan koping stres pasif terkait dengan kecemasan dan depresi yang menyebabkan peningkatan aktivitas hipotalamus dan penurunan perilaku eksplorasi (Sandi \& Haller, 2015), sehingga perilaku eksplorasi pada ikan atau hewan model lainnya dapat digunakan untuk menilai besarnya usaha adaptif terhadap respon stres (Baker et al., 2018).

\section{Uji Perilaku Novel Tank Dive}

Pengamatan uji perilaku novel tank dive mengamati durasi ikan untuk menjelajah bagian atas dan bawah tangki. Menurut Stewart et al., (2010), uji novel tank dive mirip dengan uji lapangan terbuka pada kelompok rodentia yang diasumsikan sebagai lingkungan baru pada ikan. Hasil uji perilaku dari masing-masing perlakuan dapat dilihat pada Tabel 4. 
Tabel 4. Hasil Rerata Uji Perilaku Novel Tank Dive

\begin{tabular}{l|ccccccc}
\hline \multirow{2}{*}{\multicolumn{1}{c}{ Area }} & \multicolumn{3}{c}{ K } & \multicolumn{2}{c}{ Perlakuan (detik) } & \multicolumn{2}{c}{ P2 } \\
\cline { 2 - 7 } & H+UCS & H+Induksi & H+UCS & H+Induksi & H+UCS & H+Induksi \\
\hline Bawah & 384.1 & 340.5 & 350.2 & 320.3 & 353.5 & 319 \\
Atas & 8.2 & 16.5 & 9.1 & 35.3 & 5.2 & 36.8 \\
Memasuki area atas & 3.7 & 7.4 & 2.5 & 9.5 & 2.3 & 11.9
\end{tabular}

Berdasarkan tabel diatas, rerata waktu yang dihabiskan ikan pada area atas untuk semua perlakuan menunjukkan nilai frekuensi eksplorasi yang sangat rendah setelah pendedahan UCS selama 7 hari. Kondisi tersebut diduga akibat pendedahan UCS yang berefek terhadap perilaku kecemasan, ditandai dengan tingginya durasi preferensi area bawah dan kecenderungan ikan yang tidak memasuki area atas. Menurut Darniwa et al., (2020), kecemasan pada ikan zebra dapat terlihat dari berkurangnya perilaku eksplorasi dan meningkatnya perilaku menyelam pada ikan. Perilaku ikan zebra untuk tetap menyelam atau berada pada bagian area bawah ini menyerupai perilaku tigmotaksis pada hewan pengerat. Hal ini diasumsikan sebagai perilaku berlindung dari serangan predator (Champagne et al, 2010). Menurut Collier et al., (2017), respon stres pada ikan zebra terkait sintesis kortisol yang berkolerasi dengan adanya perubahan eksplorasi.

Setelah pendedahan UCS, selanjutnya kelompok perlakuan $\mathrm{P} 1$ dan $\mathrm{P} 2$ diberikan induksi antidepresan berupa ekstrak pucuk mangga dengan konsentrasi berurutan yaitu $10 \mu \mathrm{g} / \mathrm{mL}$ dan $20 \mu \mathrm{g} / \mathrm{mL}$. Hasil uji perilaku menunjukan adanya peningkatan frekuensi waktu eksplorasi pada area atas dibandingkan dengan kelompok control yang dapat dilihat pada Gambar 2.

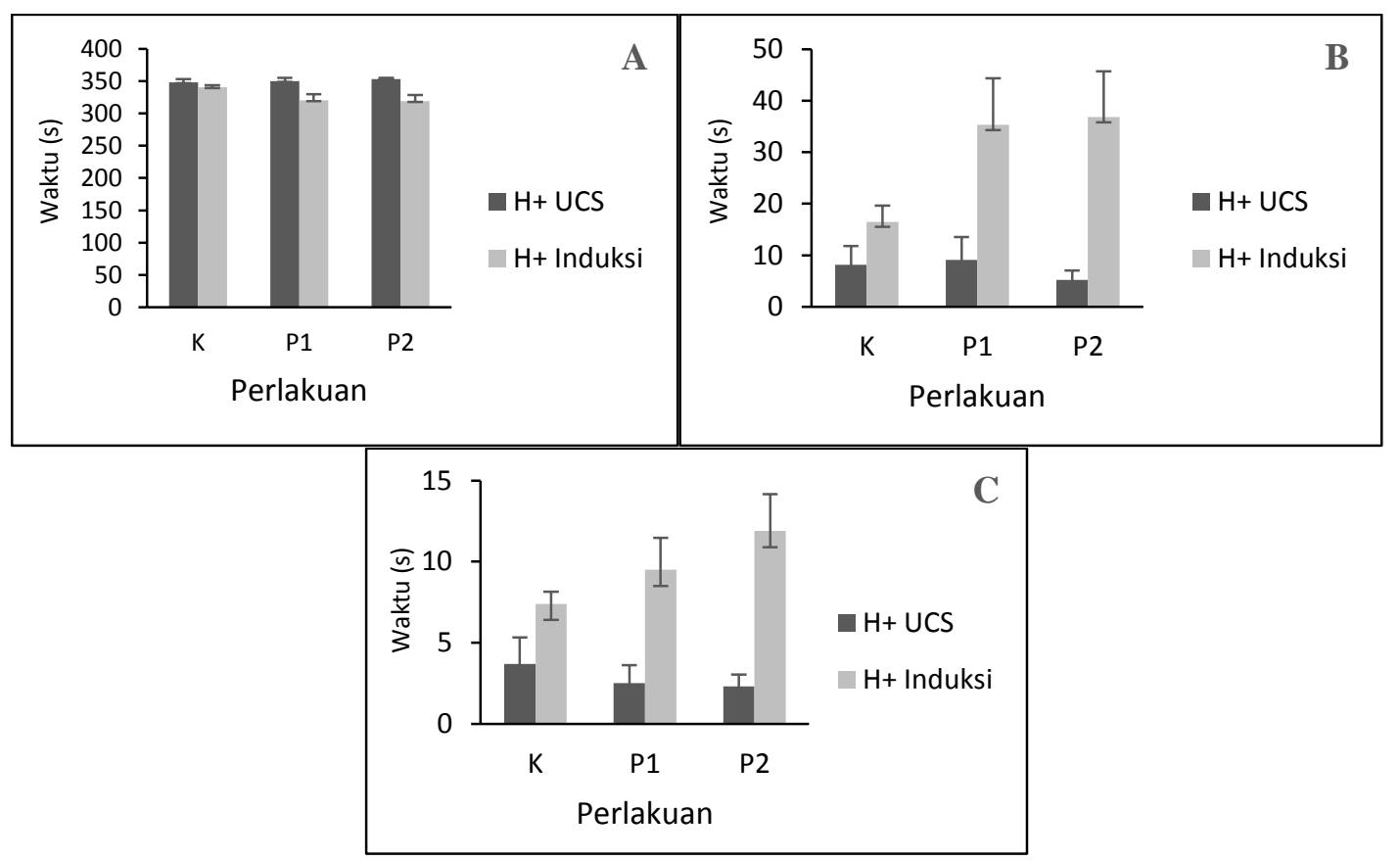

Gambar 2. Grafik hasil uji perilaku Novel Tank Dive pada (A) Area bawah, (B) Area atas, dan (C) Memasuki area atas

Sejalan dengan itu, frekuensi waktu ikan dalam memasuki area atas juga meningkat secara signifikan pada P1 dan P2. Hal ini diduga akibat adanya peran dari induksi ekstrak pucuk mangga yang telah diketahui mengandung berbagai senyawa metabolit sekunder yang dapat berperan sebagai antidepresan. Hal ini serupa dengan penelitian Egan et al., (2009) dimana pemberian 
fluoxetine (salah satu jenis obat antidepresan) pada ikan zebra memberikan efek terhadap penurunan kadar kortisol, pengurangan gerakan abnormal serta peningkatan frekuensi ikan dalam memasuki dan menghabiskan waktu di area atas. Berdasarkan uji perilaku ini, perlakuan P2 menunjukan hasil paling efektif dalam mengurangi perilaku kecemasan dengan konsentrasi ekstrak sebesar $20 \mu \mathrm{g} / \mathrm{mL}$.

\section{Uji Preferensi Terang Gelap}

Pengujian ini pada dasarnya menerapkan prinsip skotaksis (deteksi hewan lain) di mencit, begitu pula pada ikan zebra dewasa yang akan menghindari area terang dan cenderung ditempat gelap untuk menghindari hewan lain atau predatornya (Kysil et al., 2017). Hasil uji perilaku dari setiap perlakuan dapat dilihat pada Tabel 5.

Tabel 5. Hasil Rerata Uji Preferensi Terang Gelap

\begin{tabular}{lcccccc}
\hline \multirow{2}{*}{ Area } & \multicolumn{5}{c}{ Perlakuan (detik) } \\
\cline { 2 - 7 } & \multicolumn{2}{c}{ K } & \multicolumn{2}{c}{ P1 } & \multicolumn{2}{c}{ P2 } \\
& H+UCS & H+Induksi & H+UCS & H+Induksi & H+UCS & H+Induksi \\
\hline Gelap & 252.9 & 237.9 & 240 & 222.8 & 237.9 & 199.3 \\
Terang & 42.8 & 57.8 & 56.6 & 72.7 & 54 & 90.8 \\
Memasuki & 12.8 & 13.1 & 9.8 & 14.5 & 10.4 & 16.8 \\
area terang & & & & & &
\end{tabular}

Berdasarkan hasil yang diperoleh, pada periode awal setelah pendedahan UCS ketiga kelompok perlakuan cenderung menunjukan tingginya durasi yang dihabiskan pada area bawah dan rendahnya preferensi di area terang. Hal ini dimungkinkan akibat dari pendedahan UCS yang berhasil menstimulasi munculnya perilaku cemas pada hewan uji. Salah satu ciri perilaku kecemasan pada ikan zebra dapat ditandai dengan penurunan preferensi di area terang (Collier et al., 2017). Grafik perubahan perilaku eksplorasi pada uji preferensi terang gelap dapat dilihat pada Gambar 3.

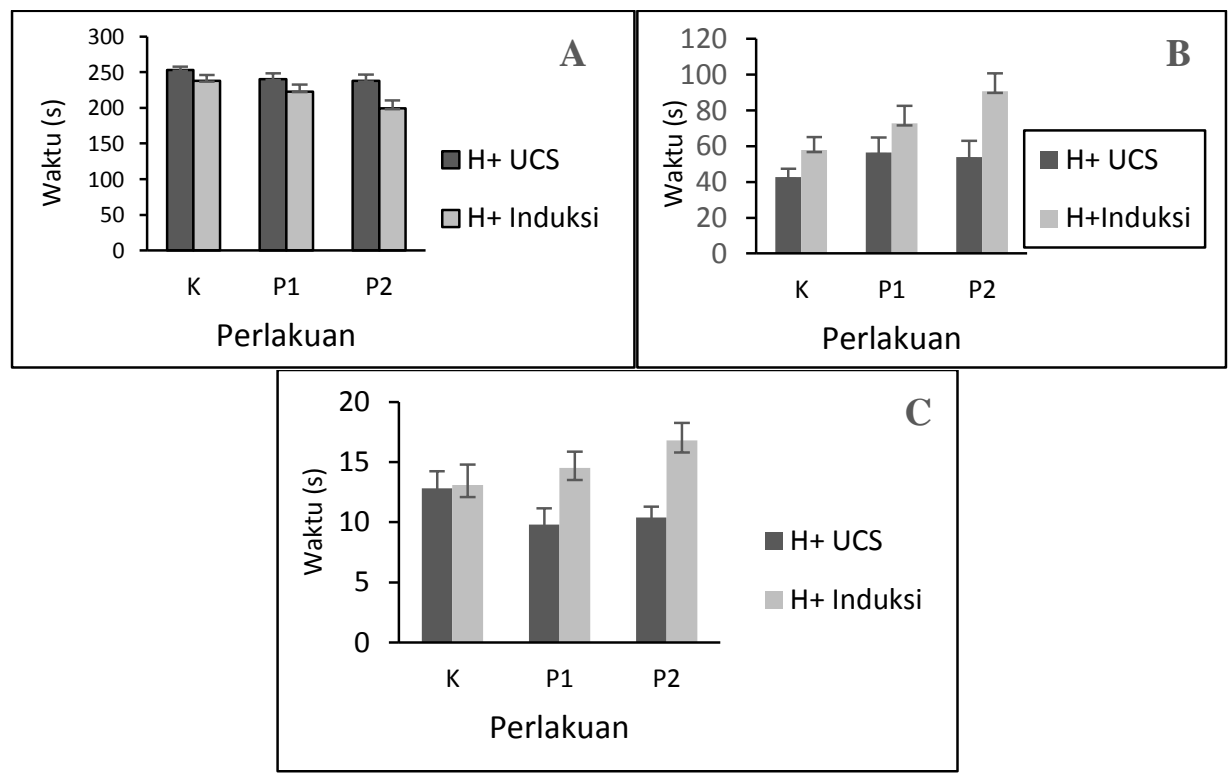

Gambar 3. Grafik hasil uji perilaku Preferensi Terang/ Gelap pada (A) Area gelap, (B) area terang, dan (C) memasuki area terang

Selanjutnya, setelah perlakuan induksi ektrak pucuk mangga pada kelompok P1 dan P2 selama 7 hari berturut-turut, hasil uji perilaku menunjukkan adanya peningkatan preferensi ikan untuk memasuki area terang dan menghabiskan waktu di area tersebut. Kelompok perlakuan P2 memiliki durasi eksplorasi area terang paling tinggi sebesar 90,8 detik atau 
mengalami kenaikan mencapai $59,4 \%$ dibandingkan dengan control (57,8 detik) dan $\mathrm{P} 1$ (72,7 detik). Hasil dari penelitian ini menunjukan kuatnya aktivitas antioksidan yang diperolah dari hasil ekstrak pucuk mangga berkorelasi positif dengan perbaikan perilaku pada hewan uji setelah pendedahan UCS.

\section{Kesimpulan}

Hasil penelitian menunjukan bahwa ekstrak pucuk mangga positif mengandung senyawa alkaloid, flavonoid, saponin dan tannin. $\mathrm{IC}_{50}$ dari pucuk mangga diperoleh nilai $8.39 \mathrm{ppm}$ dan dikategorikan sangat kuat. Selanjutnya, ekstrak pucuk mangga juga berpotensi dimanfaatkan sebagai antidepresan alami berdasarkan hasil uji perilaku pada ikan zebra dengan pendedahan Unpredictable Chronic Stress (UCS) yang ditandai dengan peningkatan eksplorasi area atas pada uji novel tank dive sebesar 36.8 detik dan area terang pada uji preferensi terang/gelap sebesar 90.8 detik dengan konsentrasi ekstrak optimum pada perlakuan P2 $(20 \mu \mathrm{g} / \mathrm{ml})$.

\section{Ucapan terima kasih}

Penulis mengucapkan Terima kasih kepada pihak Laboratorium Terpadu UIN Sunan Gunung Djati Bandung yang telah memfasilitasi tempat serta layanan pengujian dalam pelaksanaan penelitian.

\section{Referensi}

Adelina, R. (2013). Kajian Tanaman Obat Indonesia yang Berpotensi sebagai Antidepresan. Jurnal Kefarmasian Indonesia, 3(1), 9-18.

Albaar, N. M. (2015). The Antioxidant Activity of Wheatgrass Juice (Triticum aestivum) as a Health Drink with the Method DPPH. Jurnal Mkmi, 1(9), 197-202.

Aponte, A., \& Petrunich-Rutherford, M.L. (2019). Acute net stress of young adult zebrafish (Danio rerio) is not sufficient to increase anxiety-like behavior and wholebody cortisol. PeerJ, 7(8), 1-19.
Cachat, J.M., Canavello, P.R., Elkhayat, S.I., Bartels, B.K., Hart, P.C., Elegante, M.F., Beeson, E.C., Laffoon, A.L., Haymore, W.A.M., Tien, D.H., Tien, A.K., Mohnot, S., \& Kalueff, A.V. (2014). Video-Aided Analysis of Zebrafish Locomotion and Anxiety-Related Behavioral Responses. Neuromethods, 51(5).

Cahyanto, T., Fadillah, A., Ulfa, R.A., Hasby, R.M.,\& Kinasih, I. (2020). Kadar Mangiferin Pada Lima Kultivar Pucuk Daun Mangga (Mangifera indica L.). AlKauniyah: Jurnal Biologi, 13(2), 242249.

Champagne, D.L., Hoefnagels, C.C. M., de Kloet, R.E., \& Richardson, M.K. (2010). Translating rodent behavioral repertoire to zebrafish (Danio rerio): Relevance for stress research. Behavioural Brain Research, 214(2), 332-342.

Collier, A.D., Kalueff, A.V., \& Echevarria, D. J. (2017). Zebrafish Models of Anxiety-Like Behaviors. The Rights and Wrongs of Zebrafish: Behavioral Phenotyping of Zebrafish, 1-327.

Darniwa, A.V., Cahyanto, T., Kusumorini, A., Meidita, Z., Putri, E., Ulfa, R.A., Adawiyah, A., Yayu, I., \& Hizqiyah, N. (2020). Uji Perilaku dan Preferensi Area pada Ikan Zebrafish ( Danio rerio ) yang Diinduksi Stres. BIOSFER, J.Bio. \& Pend.Bio, 5(2), 32-38.

Egan, R.J., Beregner, C.L., Hart, P.C., Cachat, J. M., Canavello, P.R., Elegante, M.F., Elkhayat, S.I., Bartels, B.K., Tien, A.K., Tien, D.H., Monhot, S., Beeson, E., Glasgow, E., Amri, H., Zukowska, Z. ... \& Kalueff, A.V. (2009). Understanding behavioral and physiological phenotypes of stress and anxiety in zebrafish. Behavioural Brain Research, 205(1), 3844.

Es - safi, I., Mechchate, H., Amaghnouje, A., Jawhari, F.Z., Kamaly, O.M. Al, Imtara, H., Grafov, A., Bari, A., \& Bousta, D. (2021). An insight into the anxiolytic and 
antidepressant - like proprieties of carum carvi 1. And their association with its antioxidant activity. Life, 11(3), 1-15.

Gebauer, D.L., Pagnussat, N., Piato, Â.L., Schaefer, I.C., Bonan, C.D., \& Lara, D.R. (2011). Effects of anxiolytics in zebrafish: Similarities and differences between benzodiazepines, buspirone and ethanol. Pharmacology Biochemistry and Behavior, 99(3), 480-486.

Guilliams, T.G., \& Edwards, L. (2010). Chronic stress and the HPA axis: Clinical assessment and therapeutic considerations. The Standard, 9(2), 1-12

Hartanti, A.I., Permana, I.D.G.M., \& Puspawati, G.A.K.D. (2021). Pengaruh Konsentrasi Etanol Pada Metode Ultrasonikasi Terhadap Aktivitas Antioksidan Ekstrak Daun Gonda (Sphenoclea zeylanica). Itepa: Jurnal Ilmu dan Teknologi Pangan, 10 (20): 163-171.

Ikalinus, R., Widyastuti, S., \& Eka Setiasih, N. (2015). Skrining Fitokimia Ekstrak Etanol Kulit Batang Kelor (Moringa Oleifera). Indonesia Medicus Veterinus, 4(1), 71-79.

Kurama, N.P., Bodhi, W., \& Wiyono, W. (2013). Uji Efek Antidepresan Ekstrak Metanol Jamur Tlethong (Psilocybe Cubensis) Pada Tikus Putih Jantan (Rattus Norvegicus): Ditinjau Dari Immobility Time Dengan Metode Forced Swim Test. Pharmacon, 2(3), 29-33.

Kysil, E.V., Meshalkina, D.A., Frick, E.E., Echevarria, D.J., Rosemberg, D.B., Maximino, C., Lima, M.G., Abreu, M.S., Giacomini, A.C., Barcellos, L.J.G., Song, C. .. \& Kalueff, A.V. (2017). Comparative Analyses of Zebrafish Anxiety-Like Behavior Using ConflictBased Novelty Tests. Zebrafish, 14(3), 197-208.

Lailly, R.S.N., Komariah, C., \& Dewi, R. (2016). Efek Ekstrak Kulit Mangga Arumanis (Mangifera indica L.) terhadap Paw Licking Time Mencit Putih Jantan yang
Diinduksi Formalin. e-Jurnal Pustaka Kesehatan, 4(3), 454-457.

Muthmainnah. (2017). Skrining Fitokimia Senyawa Metabolit Sekunder dari Ekstrak Etanol Buah Delima (Punica Granatum L.) dengan Metode Uji Warna. Media Farmasi, 11(1), 92-105.

Ningsih, M., Alamsyah, Y., \& Kornialia. (2017). Uji Aktivitas Ekstrak Kulit Batang Mangga (Mangifera indica Linn) Terhadap Kadar Hambat Minimum (Khm) dan Kadar Bunuh Minimum (Kbm) Bakteri Staphylococcus Aureus Secara In Vitro pada Angular Cheilitis. B-Dent, Jurnal Kedokteran Gigi Universitas Baiturrahmah, 4(2), 150-160.

Pokorski, M. (2013). Mangiferin-A Nutraceutical with Clinical Implications. 3(1), 1-2.

Prommajak, T., Kim, S.M., Pan, C.H., Kim, S.M., Surawang, S., \& Rattanapanone, N. (2014). Identification of antioxidants in young mango leaves by LC-ABTS and LC-MS. Chiang Mai University Journal of Natural Sciences, 13(3), 317-330.

Permatasari, S., Cahyanto, T., Adawiyah, A., \& Ulfa, R.A. (2018). Pucuk Daun Mangga (Mangifera Indica L.) Kultivar Cengkir sebagai Penurun Kadar Glukosa Darah. Jurnal Biologi Dan Pembelajaran Biologi, 3(2), 102-112.

Purwanto, D., Bahri, S., \& Ridhay, A. (2017). Uji aktivitas antioksidan ekstrak buah purnajiwa. KOVALEN Jurnal Riset Kimia, 3(4), 24-32.

Rahmawati, Irma. (2020). Pengaruh Ekstrak Daun Mangga Arumanis Muda (Mangifera indica L.) terhadap Diameter Zona Inhibisi Propionibacterium Acne [Skripsi]. Malang: Universitas Muhammadiyah Malang

Rahmayani, U., Pringginies, D., \& Djunaedi, A. (2013). Uji Aktivitas Antioksidan Ekstrak Keong Bakau (Telelscopium 
Telescopium) dengan Pelarut yang Berbeda terhadap Metode DPPH. Journal of Marine Research, 2(4): 36-45.

Rambo, C.L., Mocelin, R., Marcon, M., Villanova, D., Koakoski, G., de Abreu, M.S., Oliveira, T.A., Barcellos, L.J.G., Piato, A.L. ... \& Bonan, C.D. (2017). Gender differences in aggression and cortisol levels in zebrafish subjected to unpredictable chronic stress. Physiology and Behavior, 171, 50-54.

Rinaldi F.F., Ibrahim, A., Fadraersada, J., \& Rijai, L. (2016). Identifikasi Metabolit Sekunder Dan Pengujian Toksisitas Ekstrak Metanol Kulit Kayu Laban (Vitex Pinnata L.) Dengan Metode Brine Shrimp Lethality Test (Bslt). Proceeding of Mulawarman Pharmaceuticals Conferences vol 4. Samarinda Indonesia.

Sandi, C., \& Haller, J. (2015). Stress and the social brain: Behavioural effects and neurobiological mechanisms. Nature Reviews Neuroscience, 16(5), 290-304.

Stewart, A., Kadri, F., DiLeo, J., Min Chung, K., Cachat, J., Goodspeed, J., Suciu, C., Roy, S., Gaikwad, S., Wong, K., Elegante, M., Elkhayat, S., Wu, N., Gilder, T., Tien, D., Grossman, L., Tan, J., Denmark, A., Bartels, B. ... \& Kalueff, A. (2010). The Developing Utility of Zebrafish in Modeling Neurobehavioral Disord. International Journal of Comparative Psychology, 23(1).

Tristantini, D., Ismawati, A., Pradana, B.T., \& Jonathan, J.G. (2016). Pengujian Aktivitas Antioksidan Menggunakan Metode DPPH pada Daun Tanjung (Mimusops elengi $\mathrm{L}$ Prosiding Seminar Nasional Teknik Kimia "Kejuangan", Yogyakarta, Indonesia.

Zulfiqar, Rifqi (2018). Efek Ekstrak Etanol Daun Mangga Arumanis Terhadap Kadar Glukosa Darah Mencit Yang Diinduksi Aloksan [Skripsi]. Bandung: UNJANI 